\title{
The Effect of Principal Leadership and Teacher Work Spirit on Teacher Discipline in Elementary Schools
}

\section{Leni Ofrita}

SDN 020 Jayamukti, Dumai City, 28811, Indonesia

\section{ARTICLE INFO}

\section{Article history:}

Received: 21 June 2021

Revised: 15 Jan 2022

Accepted: 16 Jan 2022

Published online: 24 Jan 2022

\section{Keywords:}

Discipline

Leadership

Spirit at Work

\begin{abstract}
A B S T R A C T
This study aims to analyze the influence of principals' leadership and teacher morale, either partially or simultaneously, on the discipline of elementary school teachers in Cluster XII, Dumai. The population of this study were all elementary school teachers in the Gugus XII area of Dumai Timur with a total sample of 92 respondents. Determination of the sample using the Probability Sampling technique. The data obtained were then analyzed descriptively. The results of the study indicate that (1) There is a positive and significant influence of principal's leadership on teacher discipline. The better the principal's leadership, the more teacher discipline will increase. (2) There is a positive and significant effect of teacher work spirit on teacher discipline. The higher the work spirit of the teacher, the more the discipline of the teacher increases. (3) There is a positive and significant influence on the leadership of the principal and the work spirit of the teacher together (simultaneously) on teacher discipline. The better the leadership of the principal and the higher the work spirit of the teacher, the better the discipline of elementary school teachers in Cluster XII, Dumai Timur.
\end{abstract}

\section{Introduction}

Teacher discipline is closely related to compliance in implementing school rules. Discipline will encourage a teacher to work in accordance with applicable regulations and procedures. Therefore, enforcing discipline is very important, because with discipline it can be seen how much the rules can be obeyed by the teacher. Teacher discipline is not just a teacher coming to teach and going home on time, but more than that it is also required behavior and actions that are in accordance with written and unwritten rules and are able to take responsibility for their duties and role as a teacher who sets an example for their students. Utami (2016) says that discipline is the ability to control oneself in the form of taking an action that is inappropriate and contrary to something that has been determined, 
and doing something that supports and protects something that has been determined. Meanwhile, according to Ekosiswoyo and Rachman in Mastur (2017), discipline is essentially a collection of individual and community behavior that reflects a sense of obedience, obedience that is supported by awareness to carry out duties and obligations in order to achieve goals.

Furthermore, according to the opinion expressed by Terry in Purwoko (2018) that the work discipline of a teacher can be seen from the teacher's compliance with the regulations that apply at school. According to Gitome et al., in Simba (2016) where there is good discipline, there is improved academic performance. Gitome's statement explains that where there is good discipline there is an increase in academic performance. From various opinions about discipline, all of them have in common that discipline is a behavior or action that prioritizes obedience and is able to control oneself in the form of actions that are not in accordance with something that has been determined.

Discipline can train and shape someone to do something good. Disciplined teachers will comply with all organizational rules and policies. In carrying out the work, the teacher is able to provide maximum service according to the field of work. To create teacher discipline, good cooperation between the principal and all components of the school environment is needed and the work spirit of the teacher himself. Based on the results of a pre-survey using a questionnaire to teachers in the Cluster XII area, the survey shows that the level of teacher discipline is not fully satisfactory with indications of arriving late, learning tools are incomplete, and do not want to improve the latest learning situation. However, this is not as easy to achieve as it is in the research environment. This condition needs to be overcome by paying attention to the teacher discipline factor.

The factors that influence teacher discipline proposed by Suroso in Sumardi (2017) are (1) work spirit, (2) employee welfare, and (3) a harmonious atmosphere. Furthermore, according to Malayu (2019) there are eight factors that can affect the level of discipline of employees in an organization, including (1) goals and abilities, (2) leadership role models, (3) remuneration, (4) fairness, (5) discretion, ( 6) punitive sanctions, (7) firmness, (8) humanitarian relations. Meanwhile, according to Harun (2017) the factors that influence teacher work discipline are (1) leadership, (2) needs, and (3) supervision. From the three opinions, there are 2 factors that are felt and suspected to play a role in the research location, namely leadership and work spirit.

The success of education in schools is largely determined by the principal in leading and making decisions to create teacher morale and manage teacher discipline in schools. In his role as a leader, the principal must be able to pay attention to the needs and feelings of the people who work so that the spirit of teacher work and teacher discipline is maintained. The success of a leader will be realized if the leader treats his subordinates well. According to Triyo Supriyatno in Salim (2016) leadership is a person's ability to influence, coordinate, mobilize, motivate, and direct people in various educational institutions so that the implementation of education and teaching can be more efficient and effective in 
achieving educational and teaching goals. Almost the same as the opinion of Stephen Robinson in Uno (2017) that leadership is the ability to influence a group to achieve the expected goals.

Furthermore, according to Sutarto in Ihsan (2019) leadership is a series of structuring activities in the form of the ability to influence the behavior of others in certain situations so that they are willing to work together to achieve organizational goals. According to Makawimbang in Rouf (2019), leadership is almost the same, namely directing, fostering, guiding and influencing. From the various opinions above, it can be seen that leadership is the ability of a person to influence (guide, encourage, direct, and move) he leads to achieve what he wants. The principal's leadership as a supervisor in supervising teacher discipline will be successful if the principal pays attention and treats teachers well so that teachers are able to show better performance as well.

There are many types of leadership. According to Gumilar (2014) there are three types of leadership, namely autocratic, laissez-faire, and democratic leadership. According to Hendiyat Soetopo and Westy Soemanto in Abdul (2017), they divide the principal leadership types into four, namely: the authoritarian type, the laissez-faire type, the democratic type and the pseudo-democratic type. From the various opinions about the type of leadership above, it can be seen that each opinion has a difference in determining the type of leadership. So it depends on the leader's self to assess including the type of leadership in leading an organization.

In addition to the leadership of the principal, the work spirit of the teacher also affects the discipline of the teacher. It can be seen from the definition of work spirit according to Hasibuan in Nasrullah (2019), namely work enthusiasm is "the desire and sincerity of a person to do his job well and be disciplined to achieve maximum work performance." Quality teachers tend to have high morale. Teachers who have high morale will be more successful than teachers who do not have enthusiasm or sincerity in their duties and are responsible. According to Moekijat in Fitria (2019), high morale will give positive attitudes such as loyalty, joy, cooperation and obedience to obligations or discipline to regulations. Meanwhile, according to Westra in Yuliani (2013) that morale is an individual or group attitude towards their volunteerism to work together in order to fully devote their abilities.

From the explanation above, it is assumed that efforts to overcome teacher discipline are influenced by leadership and work spirit. The purpose of this study is to analyze the influence of the principal's leadership and teacher's morale, either partially or simultaneously, on the discipline of elementary school teachers in Cluster XII, Dumai Timur District. 


\section{Methodology}

The type of research was survey research with a quantitative descriptive approach that refered to Sugiyono (2013). The research was carried out in an elementary school environment in Dumai Timur with a total of 5 schools. The type of data used is quantitative data. Collecting data in this study used a questionnaire (questionnaire) by providing a set of written statements to the respondents to be answered. The questionnaire contained a statement to collect research data, namely the principal's leadership, teacher morale, and teacher discipline. The data obtained from the questionnaire then be processed statistically using the SPSS application. The population of this research was all elementary school teachers in Cluster XII, Dumai Timur. The total population was 120 people, with a sample of 92 people. The sampling technique used proportionate random sampling technique. Data were collected using a questionnaire and conducted a trial first to see the validity and reliability.

\section{Results and Discussion}

\section{Teacher Discipline}

From 92 samples, a descriptive statistical picture of research data on teacher discipline was obtained. It can be seen in Table 1 below.

Table 1. Statistical Calculation of Teacher Discipline Data (Y)

\begin{tabular}{llc}
\hline No & \multicolumn{1}{c}{ Description } & Score \\
\hline 1 & Valid & 92 \\
2 & Mean & 68.17 \\
3 & Median & 69.00 \\
4 & Modus & $67^{\mathrm{a}}$ \\
5 & Std. Deviation & 6.275 \\
6 & Minimum Value & 55 \\
7 & Maximum Value & 80 \\
\hline
\end{tabular}

Based on Table 1, the average value of all teacher discipline data is 68.17 . The data above indicates that the average teacher discipline is very high because the score lies between the class intervals of $68-80$ as shown in Table 2. Thus, the distribution of elementary school teacher discipline scores in Cluster XII, Dumai Timur District is in the very high category. The spread of scores is made into 5 categories, namely very high, high, medium, low and very low. To find out the distribution category of the frequency distribution of elementary school teacher discipline data in Cluster XII, Dumai Timur District, it can be seen in Table 2. Based on Table 2, it is known that 1 respondent or $1.1 \%$ got a score in the medium category, 38 respondents or $41.3 \%$ got a score in the high category, and 32 respondents or $57.6 \%$ got a score in the very high category. 
Table 2. Categorization of Teacher Discipline Data (Y)

\begin{tabular}{|c|c|c|c|}
\hline \multirow[b]{2}{*}{ Category } & \multirow[b]{2}{*}{ Interval Class } & \multicolumn{2}{|c|}{ Frequency } \\
\hline & & Absolute & Relatif (\%) \\
\hline Very low & $20-31$ & 0 & $0 \%$ \\
\hline Low & $32-43$ & 0 & $0 \%$ \\
\hline Currently & $44-55$ & 1 & $1,1 \%$ \\
\hline High & $56-67$ & 38 & $41,3 \%$ \\
\hline Very high & $68-80$ & 53 & $57,6 \%$ \\
\hline \multicolumn{2}{|c|}{ Total } & 92 & 100 \\
\hline
\end{tabular}

\section{Principal Leadership}

From 92 samples, a descriptive statistical picture of research data on the leadership of school principals was obtained. It can be seen in Table 3 below.

Table 3. Statistical Calculation of Principal Leadership Data (X1)

\begin{tabular}{|c|c|c|}
\hline No & Description & Score \\
\hline 1 & Valid & 92 \\
\hline 2 & Mean & 89.14 \\
\hline 3 & Median & 88.00 \\
\hline 4 & Modus & $80^{\mathrm{a}}$ \\
\hline 5 & Std. Deviation & 8.938 \\
\hline 6 & Minimum Value & 68 \\
\hline 7 & Maximum Value & 106 \\
\hline
\end{tabular}

Table 3 shows that the average value of all principal leadership data is 89.14. 5 categories, namely very high, high, moderate, low and very low. To find out the category of distribution of the frequency distribution of principals' leadership data in Cluster XII, Dumai Timur District, it can be seen in Table 4 below:

Table 4. Categorization of Principal Leadership Data (X1)

\begin{tabular}{|c|c|c|c|}
\hline \multirow[b]{2}{*}{ Category } & \multirow[b]{2}{*}{ Interval Class } & \multicolumn{2}{|c|}{ Frequency } \\
\hline & & Absolute & Relatif (\%) \\
\hline Very low & $27-42$ & 0 & $0 \%$ \\
\hline Low & $43-58$ & 0 & $0 \%$ \\
\hline Currently & $59-74$ & 3 & $3,3 \%$ \\
\hline Tall & $75-90$ & 53 & $57,6 \%$ \\
\hline Very high & $91-108$ & 36 & $39,1 \%$ \\
\hline \multicolumn{2}{|c|}{ Total } & 92 & 100 \\
\hline
\end{tabular}

Based on Table 4, it is known that 3 respondents or $3.3 \%$ got a score in the medium category, 53 respondents or $57.6 \%$ got a score in the high category, and 36 respondents or $39.1 \%$ got a score in the very high category. Thus, the distribution of the leadership scores of elementary school principals in Cluster XII, Dumai Timur District is in the high category. 


\section{Teacher's Work Spirit}

From the 92 samples, a descriptive statistical picture of the research data was obtained on the morale of teachers. It can be seen in Table 5 below.

Table 5. Calculation of Teacher Morale Data Statistics (X2)

\begin{tabular}{|c|c|c|}
\hline No & Description & Score \\
\hline 1 & Valid & 92 \\
\hline 2 & Mean & 72.50 \\
\hline 3 & Median & 73.00 \\
\hline 4 & Modus & 74 \\
\hline 5 & Std. Deviation & 6.596 \\
\hline 6 & Minimum Value & 53 \\
\hline 7 & Maximum Value & 84 \\
\hline
\end{tabular}

The average value of all data on teacher morale is 72.50 . The data above indicates that the average teacher morale is high because the score lies between the 60-72 class intervals as shown in Table 6. The distribution of scores is made in 5 categories, namely very high, high, medium, low and very low. To find out the distribution category of the data distribution of the morale of elementary school teachers in Cluster XII, Dumai Timur District, it can be seen in Table 6 below:

Table 6. Categorization of Teacher Work Spirit Data (X2)

\begin{tabular}{|c|c|c|c|}
\hline \multirow[b]{2}{*}{ Category } & \multirow[b]{2}{*}{ Interval Class } & \multicolumn{2}{|c|}{ Frequency } \\
\hline & & Absolute & Relatif (\%) \\
\hline Very low & $21-33$ & 0 & $0 \%$ \\
\hline Low & $34-46$ & 0 & $0 \%$ \\
\hline Currently & $47-59$ & 1 & $1,1 \%$ \\
\hline Tall & $60-72$ & 40 & $43,5 \%$ \\
\hline Very high & $73-84$ & 51 & $55,4 \%$ \\
\hline \multicolumn{2}{|c|}{ Total } & 92 & 100 \\
\hline
\end{tabular}

Based on Table 6 , it is known that 1 respondent or $1.1 \%$ got a score in the medium category, 40 respondents or $43.5 \%$ got a score in the high category, 51 respondents or $55.4 \%$ got a score in the very high category. Thus, the distribution of the morale scores of elementary school teachers in Cluster XII, Dumai Timur District, is in the high category.

\section{Testing Requirements Analysis}

\section{Normality Test}

The results of the normality test of the three variables can be seen in Table 7 below. 
Table 7. Testing the Normality of Principal's Leadership and Teacher's Work Spirit on Teacher Discipline.

\begin{tabular}{lccc}
\hline & Teacher Discipline & $\begin{array}{c}\text { Principal } \\
\text { Leadership }\end{array}$ & $\begin{array}{c}\text { Teacher's Work } \\
\text { Spirit }\end{array}$ \\
\hline $\mathrm{n}$ & 92 & 92 & 92 \\
Asymp. Sig. (2-tailed) & $.098^{\mathrm{c}}$ & $.200^{\mathrm{c}, \mathrm{d}}$ & $.104^{\mathrm{c}}$ \\
\hline
\end{tabular}

The significance value of each of these variables is $>0.05$, which means $\mathrm{H} 0$ is accepted. Thus the requirements of the regression analysis are met.

\section{Linearity Test}

The linearity test was used to test the linearity of each independent variable on the dependent variable. It can be seen in Table 8 below.

Table 8. Linearity Test Results of Variances for Principal Leadership Variables (X1), Teacher Work Spirit (X2), and Teacher Discipline (Y)

\begin{tabular}{lll}
\hline \multicolumn{1}{c}{ Variabel } & F & Sig \\
\hline Teacher Discipline Y* Principal Leadership X1 & 1.207 & .263 \\
Teacher's Discipline Y $*$ Teacher's Work Spirit X2 & 1.500 & .102 \\
\hline
\end{tabular}

Based on Table 8. the significance value (sig) of Deviation from linearity of teacher discipline $(\mathrm{Y})$ with principal's leadership (X1) is 0.263 greater than 0.05 . So it can be concluded that there is a linear relationship between the teacher discipline variable (Y) and the principal's leadership (X1). Furthermore, the obtained significance value (sig) deviation from linearity of teacher discipline (Y) with teacher work spirit (X2) is 0.102 greater than 0.05 . So it can be concluded that there is a linear relationship between the teacher discipline variable $(\mathrm{Y})$ and the teacher's work spirit (X2).

\section{Multicollinearity Test}

The results of the multicollinearity test can be seen in Table 9 below.

Table 9. Multicollinearity Test Results for Principal Leadership Variables (X1), Teacher Work Spirit (X2), and Teacher Discipline (Y)

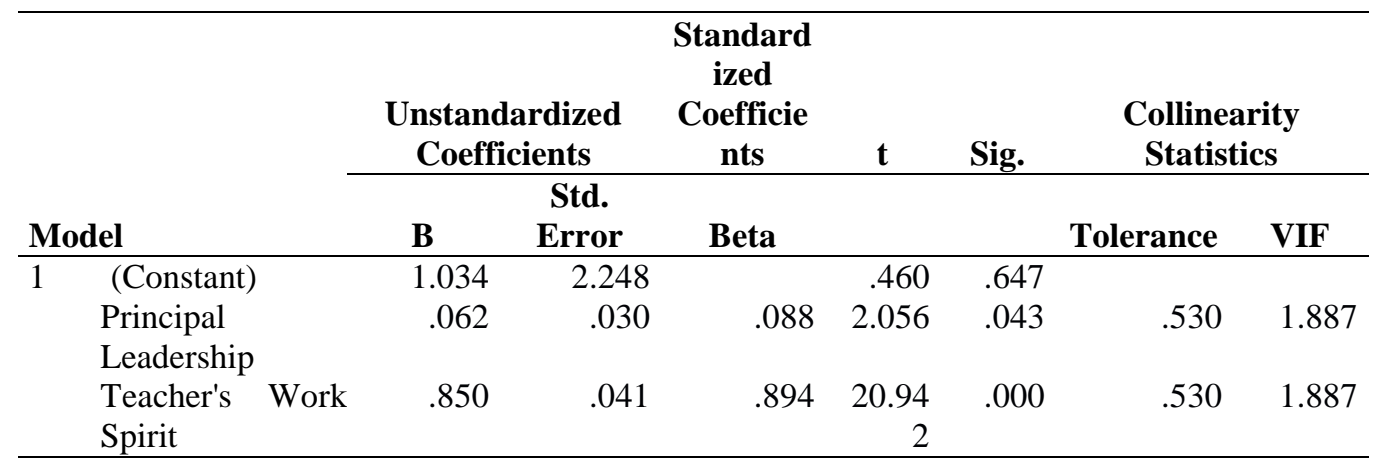


Table 9 shows that the tolerance value of the principal's leadership variable and teacher work spirit is $0.530>0.10$, which means that there is no multicollinearity between the principal's leadership variable and the teacher's morale on teacher discipline. And the VIF value of the principal's leadership variable and teacher's work spirit is $1.887<10.0$, which means that there is no multicollinearity between the principal's leadership variable and the teacher's morale on teacher discipline.

\section{Research Hypothesis Testing}

\section{Multiple Linear Regression Analysis}

The hypothesis being tested is that there is an influence between the principal's leadership and teacher morale and teacher discipline. It can be seen in Table 10 below.

Table 10. Coefficient of Multiple Linear Regression

\begin{tabular}{rlrrrrr}
\hline \multirow{2}{*}{ Model } & \multicolumn{2}{c}{$\begin{array}{c}\text { Unstandardized } \\
\text { Coefficients }\end{array}$} & $\begin{array}{c}\text { Standardized } \\
\text { Coefficients }\end{array}$ & \multicolumn{1}{c}{ t } & Sig. \\
\cline { 3 - 7 } & \multicolumn{2}{c}{ B } & Std. Error & \multicolumn{1}{c}{ Beta } & & \\
\hline 1 & (Constant) & 1.034 & 2.248 & & .460 & .647 \\
& Principal Leadership & .062 & .030 & .088 & 2.056 & .043 \\
& Teacher's Work Spirit & .850 & .041 & .894 & 20.942 & .000 \\
\hline
\end{tabular}

Based on the data obtained the value of $a=1.034$, the coefficient of $b 1=0.062$, and the coefficient of $\mathrm{b} 2=0.850$. Thus, the multiple regression equation for the teacher discipline variable (Y) on the principal leadership variable (X1) and teacher morale $(\mathrm{X} 2)$ is $=1.034+0.062 \mathrm{X} 1+0.850 \mathrm{X} 2$.

The explanations that can be given regarding the regression model are:

a. The value of 1.034 is a constant, meaning that without the influence of two other independent variables, the amount of teacher discipline has a value of 1.034

b. The regression coefficient value of the principal's leadership (X1) is 0.062 , meaning that if the other independent variables are fixed and the principal's leadership has increased by $1 \%$, the teacher's discipline (Y) will increase by 0.062 . The coefficient is positive, meaning that there is a positive influence between the principal's leadership and teacher discipline. The higher the leadership of the principal, the more disciplined the teacher will be.

c. The regression coefficient value of teacher morale (X2) is 0.850 , meaning that if the other independent variables are fixed and teacher morale has increased by $1 \%$, teacher discipline (Y) will increase by 0.850 . The coefficient is positive, meaning that there is a positive influence between the teacher's work spirit and teacher discipline. The higher the work spirit of the teacher, the more disciplined the teacher will be. 


\section{Partial Regression Coefficient Test (t Test)}

\section{The Effect of Principal Leadership (X1) on Teacher Discipline (Y) Partially}

Based on table 10. It is known that the table value is obtained from $n=92$ then $\mathrm{df}=\mathrm{n}-\mathrm{k}=92-2=90$. Seen in the $\mathrm{t}$ table with $\mathrm{df}=90$ and a significant level of $5 \%$, the t table value $=1,986$.

Table 10 imply that the Sig value for the influence of the principal's leadership (X1) on teacher discipline (Y) is 0.043 and the value of $t$ arithmetic $>t$ table is $2.056>1.986$. Thus, it can be concluded that Ha is accepted, which means that there is a partial influence of the principal's leadership on teacher discipline. From the calculation of the Standardized Coefficients Beta, the influence of the principal's leadership on teacher discipline is 0.088 , which means that in this study the principal's leadership has a small effect on teacher discipline.

\section{The Influence of Teacher's Work Spirit (X2) on Teacher Discipline (Y) Partially}

In table 10, it is known that the $\mathrm{t}$ table value is obtained from $\mathrm{n}=92$ then $\mathrm{df}=\mathrm{n}$ $\mathrm{k}=92-2=90$. Seen in the $\mathrm{t}$ table with $\mathrm{df}=90$ and a significant level of $5 \%$, the $\mathrm{t}$ table value $=1,986$.

Table 11 can be obtained that the Sig value for the effect of teacher morale (X2) on teacher discipline (Y) is 0.000 and the value of $t$ count $>t$ table is $20,942>$ 1,986. Thus, it can be concluded that Ha is accepted, which means that there is a partial influence of teacher work spirit on teacher discipline. From the calculation of the Standardized Coefficients Beta, it was found that the influence of teacher work spirit on teacher discipline was 0.894 , which means that in this study teacher work spirit had a major effect on teacher discipline.

The Effect of Principal Leadership (X1) and Teacher Work Spirit (X2) on Teacher Discipline (Y) Simultaneously.

Simultaneously, the influence of principal's leadership and teacher's morale on teacher discipline can be seen in table 11 below.

Table 11. F test (simultaneous test) Regression Model

\begin{tabular}{llrrrrr}
\hline Model & & Sum of Squares & df & Mean Square & \multicolumn{1}{c}{ F } & \multicolumn{1}{c}{ Sig. } \\
\hline 1 & Regression & 3275.458 & 2 & 1637.729 & 473.610 & $.000^{\mathrm{b}}$ \\
& Residual & 307.759 & 89 & 3.458 & & \\
& Total & 3583.217 & 91 & & & \\
\hline
\end{tabular}

Table 11 shows that the results of Fcount $=473.610>$ Ftable $=3.09$ with $\mathrm{a}$ significance level of 0.05 , then $\mathrm{H} 0$ is rejected. Thus, there is a significant influence between the principal's leadership (X1) and the teacher's morale (X2) simultaneously on teacher discipline. 


\section{Coefficient of Determination Test}

The coefficient of determination test can be seen in Table 12 below.

Table 12. Coefficient of Determination

\begin{tabular}{lrrrr}
\hline Model & R & R Square & Adjusted R Square & Std. Error of the Estimate \\
\hline 1 & $.956^{\mathrm{a}}$ & .914 & .912 & 1.860 \\
\hline
\end{tabular}

Based on Table 12, it is known that the coefficient of determination (R Square) is 0.914 or $91.4 \%$. This means that the ability of the principal's leadership variable and teacher's morale in explaining the variance of the teacher discipline variable is $91.4 \%$. It means that there is $8.6 \%$ of the variance of the teacher discipline variable explained by other factors.

\section{The Effect of Principal Leadership on Teacher Discipline Partially}

The statistical results show that the principal's leadership has a significant influence on the discipline of elementary school teachers in Cluster XII, Dumai Timur District, meaning that the better the principal's leadership, the better the teacher's discipline. On the other hand, the worse the principal's leadership, the worse the teacher's discipline.

The results of this study are in accordance with research conducted by Rifa'I (2018) with the research title The Effect of Principal Leadership on Teacher Work Discipline at SD Negeri 060794 Medan Area District. The results of M. Rifa'i's research show that there is a significant influence between the principal's leadership on the work discipline of teachers at SD Negeri 060794 Medan Area. Based on the findings of existing research, it can be concluded that the influence caused by the responsible and wise leadership of the principal has made teachers work with good discipline and on time in carrying out each of their tasks so that learning effectiveness can be achieved.

\section{The Effect of Teacher Work Spirit on Teacher Discipline Partially}

The results of this study are in accordance with research conducted by Aquasita (2021). The results of Andini et al's research resulted in a data significance value of $0.002<$ sig 0.05 which explains that work morale has a significant influence on the discipline of employees of the Regional Revenue and Asset Management Office of East Lampung Regency. Based on existing research, the work spirit variable is not found in the field of education, especially for teachers because researchers prefer work motivation variables over work enthusiasm even though work enthusiasm is included in the factors that affect teacher discipline according to experts. With this research, it was found that morale is not only present in employees and other employees but can also be studied in every teacher.

The first success of education is the factor of teachers as professional education personnel who are able to increase discipline. Teachers who have high morale 
must have high discipline as well. Thus, it can be said that the work spirit of the teacher has a positive influence on teacher discipline.

\section{The Effect of Principal Leadership and Teacher Work Spirit Together on Teacher Discipline}

The research that is believed to be relevant to the problem analysis in this study is the research conducted by Susanti (2012). The results of Aries \& Sigit's research show that work morale and leadership style have a significant positive impact on work discipline and employee performance. Thus, it can be concluded that there is an influence between the principal's leadership and work spirit on teacher discipline. In other words, the better the principal's leadership and the higher the work spirit of the teacher, the better the teacher's discipline will be.

\section{Conclusion}

From the results of this study shows that there is a positive and significant influence of the principal's leadership on the discipline of elementary school teachers in Cluster XII, Dumai Timur. The better the leadership of the principal, the more disciplined the teacher will be. There is a positive and significant influence on the work spirit of teachers on the discipline of elementary school teachers in Cluster XII, Dumai Timur District. The higher the work spirit of the teacher, the more disciplined the teacher will be. There is a positive influence of principal's leadership and teacher's work spirit on the discipline of elementary school teachers in Cluster XII, East Dumai District. The better the leadership of the principal and the higher the work spirit of the teacher, the better the discipline of elementary school teachers in Cluster XII, Dumai Timur District.

\section{References}

Abdul, R \& Syaiful, K. (2017). Kepemimpinan Pendidikan dan Budaya Mutu. Yogyakarta: Zahir Publishing.

Aquasita, A., Barusman, A. R., \& Habbiburahman, H. (2021). Pengaruh Insentif Beban Kerja dan Semangat Kerja terhadap Kedisiplinan Pegawai Dinas Pendapatan Pengelolaan Keuangan dan Aset Daerah (DPPKAD) Kabupaten Lampung Timur. Visionist, 5(1).

Fitria, A. M., Utari, W., \& Hartati, C. S. (2019). Pengaruh Lingkungan Kerja, Semangat Kerja dan Kompetensi terhadap Kinerja Guru di SMK Teknologi Bojonegoro. e-Jurnal Mitra Pendidikan, 3(5), 657-669.

Gumilar, E. W. (2014). Pengaruh Gaya Kepemimpinan Kepala Sekolah terhadap Motivasi Kerja Guru di SMAN 01 Wungu Madiun pada tahun 2013. In FIPA: Forum Ilmiah Pendidikan Akuntansi. 2( 2).

Harun, H., Sulfa, S., \& Nerlin, N. (2017). Disiplin Kerja Guru Bidang Studi Pkn di SMP Negeri 5 Kendari. SELAMI IPS, 1(45).

Ihsan, Z., \& Ardiansyah, A. (2019). Pengaruh Kepemimpinan dan Motivasi Kerja terhadap Disiplin Kerja Guru di SMP Negeri 2 Sintang. Jurnal 
Produktivitas: Jurnal Fakultas Ekonomi Universitas Muhammadiyah Pontianak, 7(1).

Malayu S.P. Hasibuan. (2019). Manajemen Sumber Daya Manusia. Edisi Revisi. Jakarta: Bumi Aksara.

Mastur, M. (2017). Pemberian Reward untuk Meningkatkan Kedisiplinan Guru dalam Mengajar di Kelas SLB. SUARA GURU, 3(3), 617-624.

Nasrullah, N. (2019). Pengaruh Budaya Organisasi, Semangat Kerja dan Iklim Kerja terhadap Kepuasan Kerja pada STMIK Bina Bangsa Kendari. JIM (Jurnal Ilmu Manajemen), 4(3), 24-36.

Purwoko, S. (2018). Pengaruh Kepemimpinan Kepala Sekolah, Komitmen Guru, Disiplin Kerja Guru, dan Budaya Sekolah terhadap Kinerja Guru SMK. Jurnal Akuntabilitas Manajemen Pendidikan, 6(2), 150-162.

Rifa'i, M. (2018). Pengaruh Kepemimpinan Kepala Sekolah terhadap Disiplin Kerja Guru di SD Negeri 060794 Kecamatan Medan Area. Manajemen Pendidikan dan Keislaman (HIJRI), 42-50.

Rouf, A. (2019). Kepemimpinan Kepala Madrasah dalam Meningkatkan Etos Kerja Guru pada MTs Pondok Besar Roudlotul Mubtadiin Balekambang Nalumsari Jepara Tahun Pelajaran 2017/2018. Tarbawi: Jurnal Keilmuan Manajemen Pendidikan, 5(01), 97-114.

Salim, N. A. (2016). Peran Kepemimpinan Kepala Sekolah dalam Meningkatkan Disiplin Kerja Guru PENDAS MAHAKAM: Jurnal Pendidikan Dasar, 1(2), 215-226.

Simba, N. O., Agak, J. O., \& Kabuka, E. K. (2016). Impact of Discipline on Academic Performance of Pupils in Public Primary Schools in Muhoroni sub-County, Kenya. .Journal of Educations and Practice, 7(6).

Sugiyono. (2013). Metode Penelitian Administrasi. Alfabeta: Bandung.

Sumardi, P. (2017). Upaya-Upaya Kepala Madrasah dalam Meningkatkan Kedisiplinan Mengajar Guru Rumpun PAI. Al-Bahtsu: Jurnal Penelitian Pendidikan Islam, 2(1).

Susanti, A, Baskoro, S.W. (2012). Pengaruh Motivasi Kerja dan Gaya Kepemimpinan terhadap Disiplin Kerja serta Dampaknya pada Kinerja Karyawan (Studi Kasus pada PT. PLN (Persero) APD Semarang). J@TI Undip, VII(20).

Uno, H. B. (2017). Teori Motivasi dan Pengukurannya. Jakarta: Bumi Aksara.

Utami, U. (2016). Peningkatan Kedisiplinan Guru melalui Budaya Semangat Pagi. Jurnal Penelitian Pendidikan Indonesia, 1(1).

Yuliani, N., \& Pratitis, N. T. (2013). Minat pada Profesi Guru, Semangat Kerja dan Kreativitas Guru Taman Kanak-Kanak. Jurnal Psikologi Tabularasa, 8(1).

How to cite this article:

Ofrita, L. (2022). The Effect of Principal Leadership and Teacher Work Spirit on Teacher Discipline in Elementary Schools in Cluster XII, Dumai Timur District. Journal of Educational Sciences, 6(1), 116-127. 